\title{
Efek Kerja Senam Jantung Sehat terhadap Kadar Kolesterol Total Klub Jantung Sehat Mitra Pegangsaan
}

\author{
Vian Octrialinanggih Pradana ${ }^{\bowtie}$, Resta Pramana \\ Program Studi Magister Pendidikan Jasmani, Pascasarjana, Universitas Negeri Jakarta, Indonesia
}

\section{Info Artikel}

\section{Sejarah Artikel:}

Diterima: Maret-2018

Disetujui: Mei-2018

Dipublikasikan : Mei-2018

\section{Kata Kunci:}

Efek kerja, Senam Jantung, Kolesterol total

\begin{abstract}
Penelitian ini bertujuan untuk mengetahui efek kerja senam jantung sehat terhadap penurunan kadar kolesterol total pada anggota klub jantung sehat mitra Pegangsaan Jakarta Pusat. Senam jantung sehat adalah olahraga yang disusun dengan selalu mengutamakan kemampuan jantung. Penelitian ini dilakukan di klub jantung sehat mitra pegangsaan Jakarta Pusat bertempat di taman RPTRA Amir Hamzah, pada tanggal 22 Oktober 2017. Metode yang digunakan adalah eksperimen dengan One Group Pretest - Posttest Design dengan teknik pengambilan sampel purposive sampling. Sampel dalam penelitian ini berjumlah 27 orang. Teknik analisis data yang digunakan adalah teknik statistik uji-t dengan menghitung nilai t-hitung dibanding dengan t-tabel pada derajat kebebasan n-1 dan taraf signifikan 0,05. Hasil perhitungan Kadar Kolesterol Total awal dan akhir setelah melakukan senam jantung sehat diperoleh selisih rata-rata (Md) 16,92 dengan standar deviasi perbedaan (SDd) 6,84. Standar error perbedaan rata-rata (SEMd) 1,34. Dalam perhitungan selanjutnya diperoleh nilai t-hitung sebesar 12,63 dan nilai t-tabel dengan derajat kebebasan (n-1) dan taraf signifikan $\alpha=0,05$ didapat sebesar 2,056. Hal ini menunjukkan bahwa hipotesa nihil (Ho) ditolak dan hipotesa alternatif (H1) diterima. Kesimpulan akhir penelitian ini ialah bahwa terdapat efek kerja senam jantung sehat terhadap penurunan kadar kolesterol total pada anggota Klub Jantung Sehat Mitra Pegangsaan, Jakarta Pusat.
\end{abstract}

\begin{abstract}
There was a research to determine the effect of heart healthy gymnastics work on decreased total cholesterol levels. The method used is experiment with One Group Pretest - Posttest. The sample in this study amounted to 27 people. This shows that the null hypothesis $\left(H_{0}\right)$ is rejected and the alternative hypothesis $\left(H_{1}\right)$ is accepted. The final conclusion of this research is that there is work effect of healthy heart gymnastics to the decrease of total cholesterol level in Healthy Heart Club member of Mitra Pegangsaan, Central Jakarta.
\end{abstract}

(C) 2018 Universitas Pendidikan Indonesia

\footnotetext{
Alamat korespondensi:

J1. Rawamangun Muka, Jakarta Timur 13220, Jakarta

E-mail: voctrialin@gmail.com
}

eISSN: 2549-6360 


\section{PENDAHULUAN}

Efek atau pengaruh merupakan akibat dari suatu hal. Sedangkan kerja artinya sesuatu yang dikerjakan atau yang dilakukan (diperbuat). Jadi efek kerja adalah kegiatan yang dilakukan oleh seseorang yang dapat menghasilkan sesuatu. Senam dapat diartikan sebagai bentuk latihan tubuh pada lantai atau alat yang dirancang untuk meningkatkan kemampuan daya tahan, kekuatan, kelentukan, kelincahan, koordinasi, keseimbangan, serta kontrol anggota tubuh (Dikpora, 2006).

Berdasarkan arti kata di atas senam jantung sehat bermakna aktifitas olahraga yang disusun dengan selalu mengutamakan kemampuan jantung, gerakan otot besar dan kelenturan sendi, agar dapat memasukkan oksigen sebanyak mungkin ke dalam tubuh (Yayasan Jantung Sehat Indonesia, 2001). Sehingga, dapat ditarik kesimpulan bahwa efek kerja senam jantung sehat adalah pengaruh dari melaksanakan olahraga yang disusun dengan selalu mengutamakan kemampuan jantung, gerakan otot besar dan kelenturan sendi, serta upaya memasukan oksigen sebanyak mungkin. Saat usia bertambah, performa jantung akan berkurang, oleh karena itu perlu dilakukan perawatan jantung. Senam jantung sangat berperan untuk menjaga kesehatan jantung karena bermanfaat memperlancar aliran darah di seluruh tubuh.

Jantung dikatakan dalam kondisi baik jika denyut nadinya normal dan stabil. Karena itu, perbaikan denyut nadi juga menjadi salah satu tujuan dalam senam jantung. Permasalahn yang sering muncul ialah tidak mudah untuk memiliki komitmen agar rutin melakukan senam jantung sehat. Alasan yang sering dilontarkan adalah karena pekerjaan sehari-hari yang sulit ditinggalkan. Padahal waktu 60 menit untuk senam jantung secara rutin sangatlah dianjurkan.

Penyusunan aktifitas senam jantung sehat disesuaikan dengan prinsip dasar olahraga untuk pembinaan kesehatan jantung dan peningkatan kesehatan jasmani yang mencukup peningkatan ketahanan jantung dan alat peredaran darah serta pernapasan atau paru (cardiorespiratory endurance) (Yayaan Jantung Sehat Indonesia., 2001) yang meliputi:

a) Kekuatan Otot (Strength)

b) Ketahanan Otot (muscle endurance)

c) Kelenturan (flexibility)

d) Koordinasi gerak (coordination)

e) Kelincahan (Agility)

f) Keseimbangan (balance)

Prinsip latihan senam jantung hampir sama dengan latihan-latihan atau olahraga yang lain pada umumnya, yaitu mengandung frekuensi, intensitas, dan tempo. Hanya saja ditambah dengan urutan dari latihan seperti pemanasan atau peregangan, latihan inti dan pendinginan.

Peregangan merupakan syarat mutlak bagi setiap permulaan aktifitas olahraga yang bertujuan untuk mencegah cedera atau robek otot. Pemanasan juga merupakan persiapan emosional, psikologis dan fisik untuk melakukan latihan (Brick, 2001). Disamping itu, peregangan dalam senam jantung sehat akan mempersiapkan tubuh menerima beban latihan, khususnya jantung dan peredaran darah. Saat peregangan kemampuan otot mulai ditingkatkan, demikian pula aliran darah ke otot-otot, sehingga otot terhindar dari beban yang tiba-tiba, yang dapat berakibat negatif. Dengan bertambahnya aliran darah, maka suhu tubuh akan meningkat pula. Hal tersebut akan membantu proses pembakaran di dalam tubuh. Kegiatan peregangan ini pada umumnya berlangsung sekitar 5-10 menit sebelum mengaplikasikan stimulus latihan atau latihan inti (Depdikbud, 1997).

Contoh bentuk-bentuk aktifitas peregangan antara lain (Senam Jantung Sehat Seri III, 2015):

a) Jalan di tempat

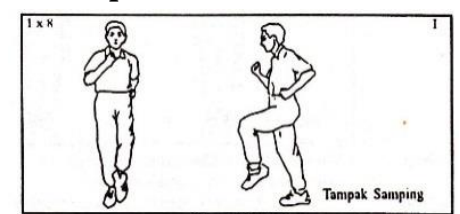

Gambar 1. Gerakan Jalan di Tempat 
b) Menundukan kepala

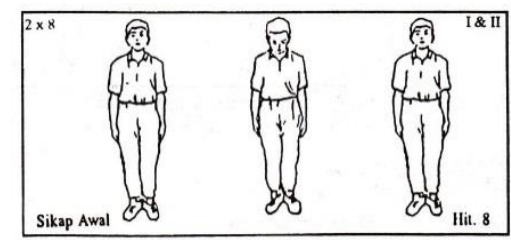

Gambar 2. Gerakan Menundukan Kepala

c) Memiringkan kepala ke kanan

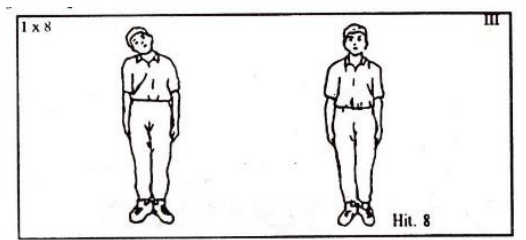

Gambar 3. Gerakan Memiringkan Kepala ke Kanan

d) Memiringkan kepala ke kiri

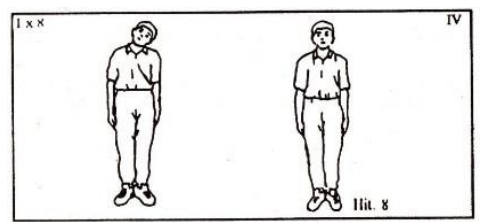

Gambar 4. Gerakan Memiringkan Kepala ke Kiri

e) Mengangkat bahu ke kanan

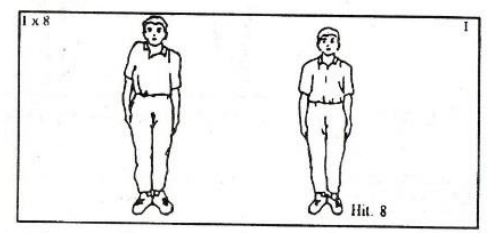

Gambar 5. Gerakan Mengangkat Bahu ke Kanan

f) Mengangkat bahu ke kiri

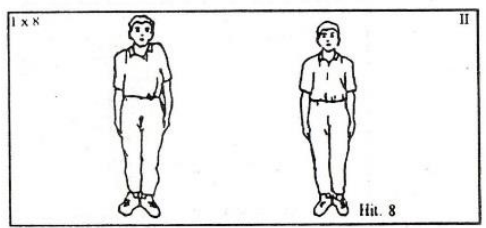

Gambar 6. Gerakan Mengangkat Bahu ke Kiri g) Mengangkat kedua bahu

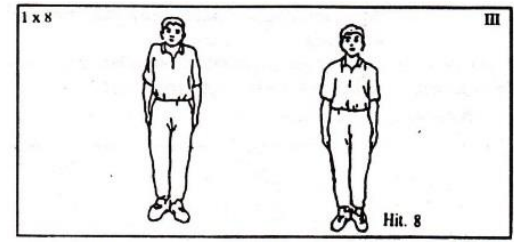

Gambar 7. Gerakan Mengangkat Kedua Bahu

h) Mengayunkan ke muka-samping dan putar lengan

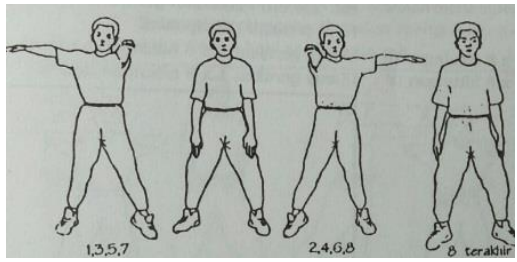

Gambar 8. Gerakan Mengayunkan ke MukaSamping dan Putar Lengan

i) Menggerakan dada, lengan dan punggung

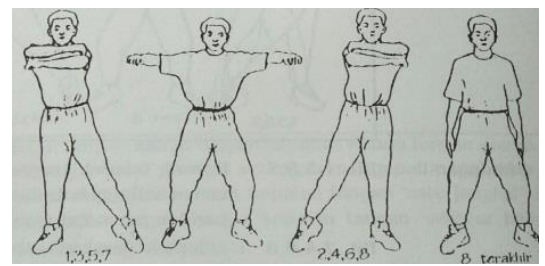

Gambar 9. Gerakan Menggerakan dada, lengan dan punggung

Latihan inti adalah latihan yang melibatkan kekuatan otot, keseimbangan, kordinasi gerak, kelincahan, ketahan otot, dan kelenturan. Contoh bentuk latihan inti antara lain (Senam Jantung Sehat Seri III, 2015):

j) Jalan di tempat dan melangkah maju mundur

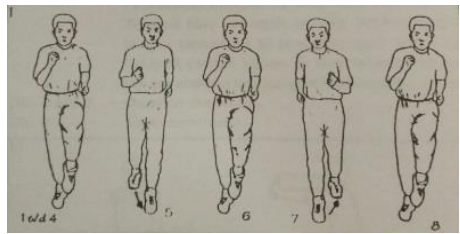

Gambar 10. Gerakan Jalan di Tempat dan Melangkah Maju Mundur 
k) Silang-buka lengan di muka paha

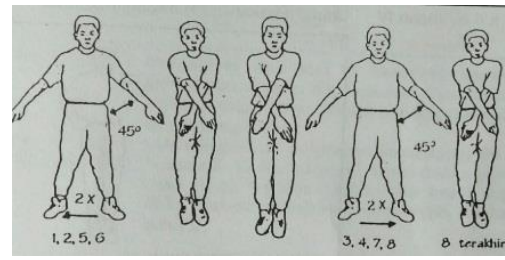

Gambar11. Gerakan Silang-Buka Lengan di Muka Paha

1) Lurus-tekuk siku setinggi bahu

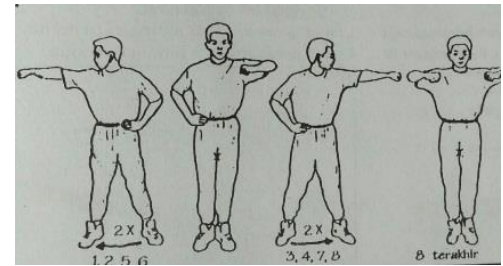

Gambar 12. Lurus-tekuk Siku Setinggi Bahu

m) Ayun siku ke atas-bawah dan luruske muka

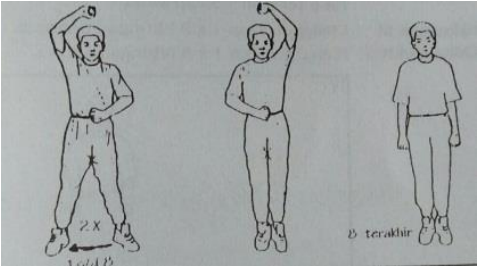

Gambar 13. Gerakan Ayun Siku ke AtasBawah Dan Luruske Muka

n) Mendorong lengan ke muka dan atas

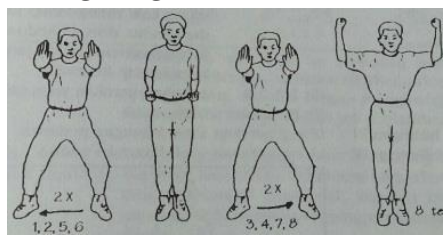

Gambar 14. Gerakan Mendorong Lengan ke Muka dan Atas

o) Angkat siku dan dorong telapak tangan

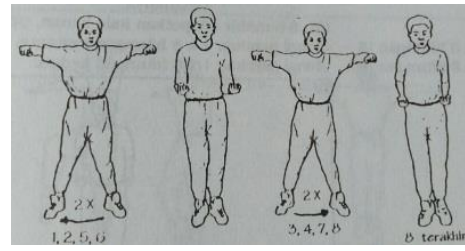

Gambar 15. Gerakan Angkat Siku dan Dorong Telapak Tangan p) Luruskan lengan bawah dan silang lengan

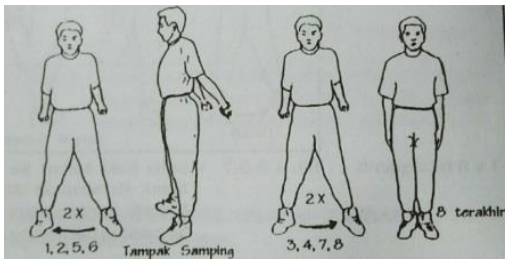

\section{Gambar 16. Gerakan Luruskan Lengan}

Bawah dan Silang Lengan

Sedangkan yang dimaksud pendinginan adalah mengembalikan kondisi tubuh manusia sebelum latihan, agar denyut jantung dan pernapasan berangsur pulih dan kembali. Pendinginana menyebabkan otot-otot yang sudah bekerja kembali lemas dan menghilangkan sisa-sisa pembakaran oleh karena itu gerakan pendinginan bersifat pelan dan santai serta lemas. Otot tidak diregangkan sebagaimana saat peregangan, tetapi justru dilemaskan atau dikendorkan oleh sebab itu kebanyakan gerakan peregangan dinamis dan statis. Beberapa bentuk gerakan pendinginan senam jantung sehat antara lain (Senam Jantung Sehat Seri III, 2015):

q) Mengayunkan tangan ke samping dan atas

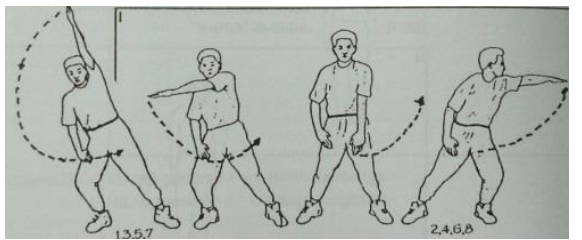

Gambar 17. Gerakan Mengayunkan Tangan ke Samping dan Atas

r) Mengangkat lengan ke atas dan samping

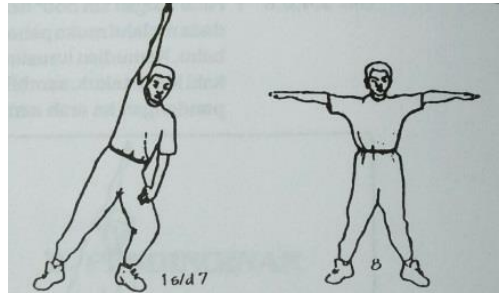

Gambar 18. Gerakan Mengangkat Lengan ke Atas dan Samping 
s) Menahan lengan di atas

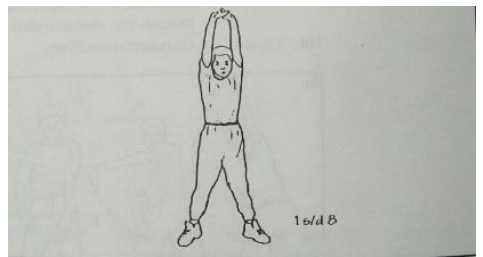

Gambar 19. Gerakan Menahan Lengan di

Atas

t) Menekuk siku ke atas dan sikap sempurna

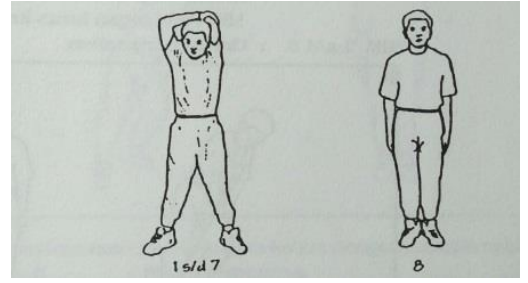

Gambar 20. Gerakan Menekuk Siku ke Atas dan Sikap Sempurna

u) Meluruskan lengan dan kaki ke belakang

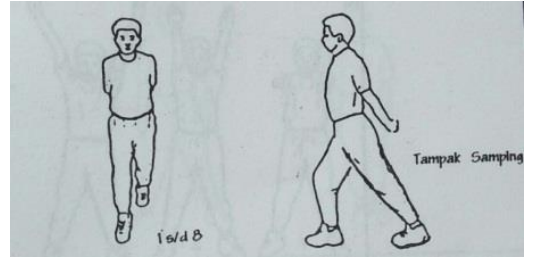

Gambar 21. Gerakan Meluruskan Lengan dan Kaki ke Belakang

v) Meluruskan kaki kanan dan menekuk kaki kiri
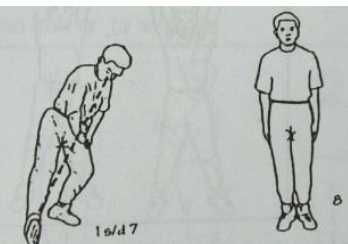

\section{Gambar 22. Gerakan Meluruskan Kaki Kanan} dan Menekuk Kaki Kiri

Olahraga senam jantung sehat merupakan olahraga yang bersifat aerobik, jenis aktivitas fisik yang di lakukan pada tingkat intensitas yang sedang untuk jangka waktu tertentu. Dalam hal ini, oksigen di gunakan untuk "membakar" lemak dan gula darah guna menghasilkan adenosine trifosfat yang merupakan pembawa dasar energi di tingkat sel. Kerja senam jantung sehat ini adalah usaha untuk memperlancar alirah darah ke jantung menghindarkan terjadinya penyakit pembuluh darah. Dalam melakukan aktifitas menggunakan energi dalam tubuh, Energi tersebut dibentuk di dalam mitokondria melaui reaksi aerobik, Reaksi tersebut adalah:

Glycogen \& Free Fatty Acid (FFA) + phospat $+\mathrm{ADP}+\mathrm{O}_{2} \quad \mathrm{CO}_{2}+\mathrm{H} 2 \mathrm{O}+\mathrm{ATP}$. (Rodahi, 1996)

Reaksi aerobik merupakan reaksi kimia yang menggunakan $\mathrm{O}_{2}$ dan proses aerobik merupakan kondisi yang cukup oksigen. Jadi didalam mitokondria terjadi reaksi Glicogen dan Free Fatic Acid + Phospat + Adinosin Diphospat ditambahkan oksigen akan menghasilkan $\mathrm{CO}_{2}$ sebagai sisa pembakaran dan $\mathrm{H}_{2} \mathrm{O}$ akan menghasilkan ATP (adenosine triphospate).yang kemudian digunakan sebagai sumber energi untuk kontraksi otot. Penggunaan lemak untuk energi apabila melakukan intensitas waktu olahraga yang lama (30-60 menit) (Pate, 1993)

Sebelum terjadi reaksi aerobik, ketika memulai suatu latihan yang menjadi sumber energi adalah energi yang didapat dari reaksi anaerobik, yaitu reaksi yang tidak memerlukan suplai oksigen. Biasanya reaksi ini terjadi pada 2 menit awal melakukan latihan. Oleh karena kapasitas dari reaksi anaerobik ini terbatas, maka orang akan cepat merasa lelah. Ketika telah merasa lelah, barulah sistem aerobik akan berlangsung yang menghasilkan ATP untuk sumber energi dalam melanjutkan latihan tersebut. Sistem aerobik ini dapat menghasilkan kapasitas yang jauh lebih besar dibandingkan sistem anaerobik sehingga seseorang dapat melakukan latihan sampai beberapa jam lamanya (Hairy, 2003).

Pada saat berolahraga, terdapat 3 jalur metabolisme energi yang dapat digunakan oleh tubuh untuk menghasilkan ATP yaitu hidrolisis phosphocreatine (PCr), glikolisis anaerobik glukosa serta pembakaran simpanan karbohidrat, lemak dan juga protein. Pada kegiatan olahraga dengan aktivitas aerobik yang dominan, metabolisme energi akan berjalan melalui pembakaran simpanan karbohidrat, lemak dan sebagian kecil $( \pm 5 \%)$ dari pemecahan simpanan protein yang terdapat di dalam tubuh 
untuk menghasilkan ATP. Pada awal latihan olahraga aerobik sumber utama yang dipergunakan adalah glukosa yang berasal dari glikogen di otot-otot. Apabila latihan terus dilanjutkan maka sumber tenaga dari glikogen otot berkurang, selanjutnya akan terjadi pemakaian glukosa darah dan asam lemak bebas. Makin ditingkatkan porsi latihan maka akan meningkat pemakaian glukosa yang berasal dari cadangan glikogen. Bila latihan dilanjutkan lagi maka sumber tenaga terutama berasal dari asam lemak bebas hasil lipolisis jaringan lemak.

Aktifitas aerobik ialah kegiatan atau gerak badan atau olahraga yang menuntut lebih banyak oksigen untuk memperpanjang waktu dan memaksa tubuh untuk memperbaiki sistemnya hingga bertanggung jawab untuk transportasi lebih banyak oksigen. Beberapa keuntungan aerobik sebagai berikut :

Jumlah volume oksigen bertambah hingga badan dapat lebih terlengkapi untuk mentransportasikan oksigen sehingga seseorang akan mempunyai daya tahan yang lebih kuat bila berhadapan dengan kegiatan fisik yang berat.

Kepasitas paru-paru bertambah. Banyak penelitian menunjukan bahwa lebih besar kapasitas paru-paru berarti lebih panjang umur anda.

Otot jantung akan lebih kuat, dan dapat lebih baik dalam menyalurkan darah. Ini berarti pada setiap denyutan jantung lebih banyak darah yang dapat di pompakan jantung tersebut.

High Density Lipoprotein (HDL) bertambah, dan perbandingan jumlah kolesterol dan high density lipoprotein (HDL) akan berkurang, sehingga mengurangi resiko untuk mengembangkan arterosklerosis atau pengerasan arteri yang mengakibatkan serangan jantung.

Kolesterol adalah suatu zat yang esensial yang digunakan untuk membentuk hormon, asam empedu, membran kulit sel, dan lapisan pelindung disekeliling saraf (Fatmah, 2010). Kolesterol sangat penting bagi tubuh sehingga tubuh memerlukan zat tersebut untuk melakukan suatu metabolisme tubuh. Sumber kolesterol ada 2 yaitu kolesterol eksogen yang berasal dari makanan yang kita makan seharihari, dan kolesterol endogen yang dibuat dalam sel tubuh terutama hati.

Kolesterol banyak terkandung dalam lemak, yaitu kelompok asam yang pada dasarnya melekat pada rantai karbon atom, dengan dua atom hidrogen ditambahkan pada masing-masing seperti minyak parapin anorganik (Lean, 2013). Sebagian besar lemak dalam darah terdiri atas trigliserida. Lemak di bedakan dalam dua jenis yaitu, lemak jenuh yang dikenal sebagai Low Density Lipoprotein $(L D L)$ dan lemak tak jenuh yang dikenal sebagai High Density Lipoprotein (HDL).

Lemak jenuh dalam makanan merusak kemampuan hati untuk mengeluarkan kolesterol dari dalam darah, sehingga mengakibatkan meningkatnya level kolesterol dan memperbesar endapan kolesterol didalam arteri koroner dan arteri-arteri lain. Lemak jenuh merupakan asam lemak yang dalam struktur kimianya tidak memiliki ikatan rangkap pada rantai karbon.

Jumlah seluruh kandungan kolesterol dalam darah disebut sebagai kolesterol total, yaitu kadar keseluruhan kolesterol yang beredar dalam tubuh manusia. Juumlah koleterol total berkisar antara 150-250 mg\% (Baraas, 1993). Nilai kolesterol total merupakan gabungan beberapa level kolesterol yang jenisnya berbedabeda, terutama kolesterol lipoprotein (senyawa gabungan lemak dan protein yang disintesis hati) berkepadatan rendah (LDL), yang populer diketahui kolesterol "buruk", dan kolesterol berkepadatan tinggi (HDL), atau kolesterol "baik", dan kolesterol berkepadatan sangat rendah (VLDL).

Kolesterol yang baik adalah HDL, terdiri dari lebih banyak protein dengan sedikit kolesterol dan trigliserida, suatu substansial lemak yang lain. Adapun LDL terdiri dari sedikit protein dan sejumlah besar kolesterol dan trigliserida. 
Tabel 1. Kadar Kolesterol Dalam Darah Orang Sehat (mg/dl) (Garnadi, 2011)

\begin{tabular}{|c|c|c|}
\hline \multirow[t]{3}{*}{$\begin{array}{l}\text { Jenis Kolesterol } \\
\text { Kolesterol total }\end{array}$} & $\begin{array}{l}\text { Kadar Kolesterol } \\
\quad<200 \mathrm{mg} / \mathrm{dl}\end{array}$ & $\begin{array}{c}\text { Kategori } \\
\text { Yang diinginkan }\end{array}$ \\
\hline & $200-239 \mathrm{mg} / \mathrm{dl}$ & Batas tinggi \\
\hline & $>240 \mathrm{mg} / \mathrm{dl}$ & Tinggi \\
\hline \multirow[t]{3}{*}{ Kolesterol HDL } & $<40 \mathrm{mg} / \mathrm{dl}$ & Rendah \\
\hline & $40-59 \mathrm{mg} / \mathrm{dl}$ & $\begin{array}{c}\text { Lebih tinggi-lebih baik } \\
\text { Tinggi, }\end{array}$ \\
\hline & $>60 \mathrm{mg} / \mathrm{dl}$ & Sangat baik \\
\hline \multirow[t]{5}{*}{ Kolesterol LDL } & $<100 \mathrm{mg} / \mathrm{dl}$ & Optimal \\
\hline & $100-129 \mathrm{mg} / \mathrm{dl}$ & Mendekati optimal \\
\hline & $130-159 \mathrm{mg} / \mathrm{dl}$ & Batas tinggi \\
\hline & $160-189 \mathrm{mg} / \mathrm{dl}$ & Tinggi \\
\hline & $>190 \mathrm{mg} / \mathrm{dl}$ & Sangat tinggi \\
\hline \multirow[t]{4}{*}{ Trigliserida } & $<150 \mathrm{mg} / \mathrm{dl}$ & Normal \\
\hline & $150-199 \mathrm{mg} / \mathrm{dl}$ & Batas tinggi \\
\hline & $200-499 \mathrm{mg} / \mathrm{dl}$ & Tinggi \\
\hline & $>500 \mathrm{mg} / \mathrm{dl}$ & Sangat tinggi \\
\hline
\end{tabular}

Kadar kolesterol yang tinggi dapat berpengaruh terhadap kesehatan, terutama pada pembuluh darah, yang biasanya menyebabkan beberapa penyakit seperti serangan jantung, penyakit jantung dan stroke.

Salah satu cara untuk mengatasinya yaitu dengan latihan fisik atau olahraga. Olahraga dapat meningkatkan kadar high density lipoprotein (HDL). Peningkatan kadar HDL akibat olahraga di sebabkan adanya pembakaran lemak sebagai sumber energi, sehingga terjadi penurunan trigliserida dan VLDL yang akhirnya menyebabkan HDL meningkat.

Olahraga juga akan menurunkan aktifitas enzim lipase dalam hati, sehingga menghambat katabolisme HDL. Jika seseorang melakukan satu kali latihan olahraga, maka hal ini dapat menyebabkan kenaikan kadar HDL di dalam darah, meskipun kadar tersebut akan turun lagi menjadi normal dalam beberapa hari. Jadi 
kuncinya adalah agar kadar HDL tinggi adalah latihan yang teratur.

Dalam sebuah latihan olahraga intensitas merupakan hal yang harus di perhatikan. Intensitas adalah kerasnya kita melakukan latihan, khususnya latihan yang bersifat aerobik. Intensitas latihan di tandai dengan tercapainya tingkat denyut nadi yang di harapkan meningkat (Dinata, 2010).

Untuk melatih jantung, maka setiap rangkaian gerakan haruslah mampu meningkatkan beban latihan agar dosis latihan atau denyut nadi terpelihara. Selama

Maksimal $=200-$ umur per menit untuk mengetahui bahwa latihan tersebut telah tercapai.

Sebagai contoh, seseorang yang berusia 40 tahun maka maksimal pulse orang tersebut adalah $200-40=160$ denyut $/$ menit dan untuk target zone orang tersebut sebaiknya $70 \%-85 \%$ dari maximal pulse, yaitu sebagai berikut: minimal pulse $=0,7 \times 160$ denyut $/$ menit $=112$ denyut $/$ menit. Maximal pulse $=0,85 \times 160$ denyut $/$ menit $=136$ denyut $/$ menit. Jadi target zone untuk orang tersebut yang berusia 40 tahun adalah 112-136 denyut/menit.

Gerakan yang dilakukan pada setiap persendian, hendaklah diikuti dengan benar dan sungguh-sungguh agar hasil kerja otot memberikan efek optimal, serta mampu mengoreksi sikap dan gerak yang salah sehingga akan mampu meningkatkan kecepatan gerak sehingga tercapai gerakan yang berkualitas. Pada akhir gerakan Senam Jantung Sehat, sengaja ada pemacuan denyut jantung dengan menambah beban latihan.

Di indonesia terdapat beberapa organisasi dibidang olahraga yaitu salah satunya ialah Yayasan Jantung Sehat Indonesia yang bertujuan untuk kegiatan promotif, preventif dan rehabilitatif untuk masyarakat. Khusus untuk di daerah Jakarta pusat terdapat klub senam jantung Mitra Pegangsaan.

Klub jantung sehat mitra ini bernaung dibawah Yayasan Jantung Sehat Indonesia yang merupakan salah satu klub jantung sehat yang dalam pelaksanaanya memberikan treatment kepada anggotanya berupa latihan-latihan yang berolahraga, gerakkan harus tetap dijaga pada ambang aman. Ambang yang aman ialah, bila aktifitas olahraga hanya mencapai $70 \%-85 \%$ dari maksimal pulse yang disebut training zone (Kadir, 2007).

Adapun rumus umum untuk menentukan denyut nadi maksimal atau maximal pulse yaitu 220 dikurangi usia saat ini (Harsuki, 2003). Namun klub jantung sehat menetapkan bahwa denyut nadi latihan adalah:

Minimal $=(3 / 4 \times$ nadi maksimal $)$ per menit

Optimal $=($ nadi maksimal -10$)$ per menit mengandung aerobik untuk melatih sistem kardiovaskuler dan juga mempengaruhi tingkat kesegaran jasmani pada para anggotanya.

Sebanyak 59 orang yang terdaftar secara resmi sebagai anggota Klub Jantung Sehat Mitra Pegangsaan merupakan perempuan yang ratarata berusia 30-60 tahun. Para anggota Klub Jantung Sehat Mitra Pegangsaan yang berlatar belakang ibu rumah tangga dan pegawai ini mengikuti latihan senam jantung sehat setiap hari minggu mulai pukul 06.00 pagi sampai selesai bertempat di taman RPTRA Amir Hamzah. Saat latihan mereka pun dipimpin oleh instruktur yang telah lolos diseleksi oleh Yayasan Jantung Sehat Indonesia.

Berdasarkan observasi awal didapati bahwa sebagian besar anggota Klub Jantung Sehat Mitra Pegangsaan memiliki riwayat kolesterol tinggi. Para anggota tersebut berkeyakinan dengan bergabung dengan kegiatan senam jantung sehat akan mengurangi resiko mereka terkena serangan jantung akibat kadar kolesterol tinggi. Pengalaman yang mereka rasakan terdapat perubahan kondisi tubuh yang lebih segar setelah melaksanakan senam jantung sehat. Peneliti menduga ada peran senam jantung sehat dalam kondisi kolesterol tubuh para anggota klub tersebut.

Berdasarkan kerangka teori dan kerangka berpikir yang telah dikemukakan di atas, pada bagian ini dibuat hipotesa, yang selanjutnya akan dibuktikan kebenarannya melalui penelitian yang dilakukan. Hipotesa yang diajukan dalam penelitian ini adalah: Terdapat efek kerja senam jantung sehat terhadap 
penurunan kadar kolesterol total pada anggota Klub Jantung Sehat Mitra Pegangsaan, Jakarta Pusat.

\section{METODE}

Penelitian ini bertujuan untuk mengetahui efek kerja senam jantung sehat terhadap penurunan kadar kolesterol total pada anggota Klub Jantung Sehat Mitra Pegangsaan, Jakarta Pusat.

Metode penelitian ini menggunakan metode penelitian eksperimen untuk mencari perbedaan tingkat kadar kolesterol sebelum dan sesudah treatment menggunakan one group pretest and post-test design.

Prosedur dalam desain penelitian ini ialah, sebelum melakukan treatment senam jantung sehat sampel di beri pre-test (tes awal) dan setelah melakukan senam jantung sehat, sampel di beri post-test (tes akhir).

Dalam penelitian ini yang akan menjadi populasi adalah anggota Klub Senam Jantung Sehat Mitra Pegangsaan, Jakarta Pusat. Sampel diambile secara purposive karena diharapkan memiliki kriteria tertentu. Kriteria yang dimaksud ialah dengan melakukan tes awal pengambilan darah untuk mengetahui kadar kolesterol total pada sampel sebelum melakukan senam jantung sehat. Kemudian yang kedua adalah sampel yang melakukan Senam Jantung Sehat selama 60 menit. Jika sampel tidak mengikuti tes awal dan aktifitas senam selama waktu yang ditentukan maka sampel dianggap gagal memenuhi kriteria penelitian.

Jumlah sampel awal penelitian sebanyak 30 orang. Pada saat pengecekan kadar kolesterol total sebelum melakukan senam 30 orang melakukan cek kadar kolesterol total. Kemudian ada 3 orang sampel tidak mencapai batas waktu yang ditentukan. Dengan demikian jumlah sampel yang dipakai dalam penelitian ini ialah 27 orang.

Treatment berupa aktifitas senam jantung sehat dilakukan secara simultan yang meliputi kegiatan peregangan selama 15 menit berupa gerakan jalan di tempat, gerakan menundukan kepala, memiringkan kepala ke kanan, gerakan memiringkan kepala ke kiri, gerakan mengangkat bahu ke kanan, gerakan mengangkat bahu ke kiri, gerakan mengangkat kedua bahu gerakan mengayunkan ke mukasamping dan putar lengan, serta gerakan menggerakan dada, lengan dan punggung.

Dilanjutkan aktifitas inti dilakukan selam 30 menit yang berupa gerakan jalan di tempat dan melangkah maju mundur, gerakan silang- buka lengan di muka paha, lurus-tekuk siku setinggi bahu, gerakan mendorong lengan ke muka dan atas gerakan angkat siku dan dorong telapak tangan serta gerakan luruskan lengan bawah dan silang lengan.

Treatmen kemudian diakhiri dengan pendinginan yang berupa gerakan mengayunkan tangan ke samping dan atas, gerakan mengangkat lengan ke atas dan samping, gerakan menahan lengan di atas, gerakan menekuk siku ke atas dan sikap sempurna, gerakan meluruskan lengan dan kaki ke belakang serta gerakan meluruskan kaki kanan dan menekuk kaki kiri.

\section{HASIL DAN PEMBAHASAN}

Dekripsi data pada penelitian ini meliputi nilai tertinggi, nilai rata-rata, standar deviasi, standar error, distribusi frekuensi, serta histrogram dari masing - masing variabel. Berikut data lengkapnya:

\section{Data Hasil Tes Awal Kadar Kolesterol Total}

Data yang terkumpul mengenai penurunan kadar Kolesterol Total pada tes awal menunjukkan rentangan nilai tertinggi 296 $\mathrm{mg} / \mathrm{dl}$ dan nilai terendah $109 \mathrm{mg} / \mathrm{dl}$ dengan rata-rata 199,88 $\mathrm{mg} / \mathrm{dl}$, standar deviasi (SD) sebesar 40,31 standar error (SE) sebesar 7,92. Hal tersebut dapat terlihat pada distribusi frekuensi dan histrogram berikut:

Tabel 2. Distribusi Frekuensi Tes Awal Kadar Kolesterol Total

\begin{tabular}{|c|c|c|c|c|}
\hline No & $\begin{array}{c}\text { Kelas } \\
\text { Interval }\end{array}$ & $\begin{array}{c}\text { Nilai } \\
\text { Tengah }\end{array}$ & Frekuensi & Persentase \\
\hline 1 & $109-142$ & 125,5 & 3 & $11,11 \%$ \\
\hline 2 & $143-176$ & 159,5 & 1 & $3,70 \%$ \\
\hline 3 & $177-210$ & 193,5 & 13 & $48,15 \%$ \\
\hline 4 & $211-244$ & 227,5 & 7 & $25,93 \%$ \\
\hline 5 & $245-278$ & 261,5 & 1 & $3,70 \%$ \\
\hline 6 & $279-312$ & 295,5 & 2 & $7,41 \%$ \\
\hline & Jumlah & & 27 & $100 \%$ \\
\hline
\end{tabular}

Apabila data tersebut diklasifikasikan dalam rentangan kadar kolesterol maka sebanyak 17 sampel atau $62,69 \%$ tergolong memiliki kadar kolesterol yang baik $(<200 \%$ $\mathrm{mg} / \mathrm{dl})$. Terdapat 7 orang atau $25 \%$ dari sample 
yang tergolong memiliki kadar kolesterol diambang batas tinggi $(200<\mathrm{x}>240 \mathrm{mg} / \mathrm{dl})$ serta 3 orang atau $11,11 \%$ memiliki kadar kolesterol yang tinggi (>240 mg/dl).

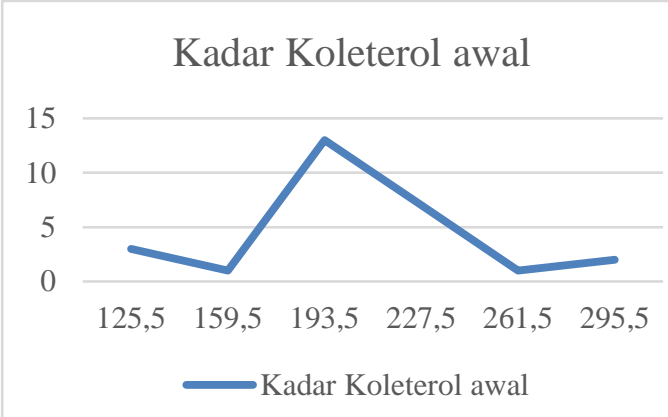

\section{Gambar 23. Grafik Data Tes Awal Kadar Kolesterol Total}

\section{Data Hasil Tes Akhir Kadar Kolesterol Total}

Data yang terkumpul mengenai data Kolesterol Total pada tes akhir setelah senam jantung sehat menujukkan rentangan nilai tertinggi $275 \mathrm{mg} / \mathrm{dl}$ dan nilai terendah 100 $\mathrm{mg} / \mathrm{dl}$ dengan rata-rata $182,96 \mathrm{mg} / \mathrm{dl}$, standar deviasi (SD) sebesar 40,08 standar error (SE) sebesar 7,87. Hal tersebut dapat terlihat pada distribusi frekuensi dan histrogram berikut.

Tabel 3. Distribusi Frekuensi Tes Akhir Kadar Kolesterol Total

\begin{tabular}{|c|c|c|c|c|}
\hline No & $\begin{array}{c}\text { Kelas } \\
\text { Interval }\end{array}$ & $\begin{array}{c}\text { Nilai } \\
\text { Tengah }\end{array}$ & Frekuensi & Persentase \\
\hline 1 & $100-131$ & 115,5 & 3 & $11,11 \%$ \\
\hline 2 & $132-163$ & 147,5 & 4 & $14,81 \%$ \\
\hline 3 & $164-195$ & 179,5 & 11 & $40,74 \%$ \\
\hline 4 & $196-227$ & 211,5 & 5 & $18,52 \%$ \\
\hline 5 & $228-259$ & 243,5 & 2 & $7,41 \%$ \\
\hline 6 & $260-291$ & 275,5 & 2 & $7,41 \%$ \\
\hline & Jumlah & & 27 & $100 \%$ \\
\hline
\end{tabular}

Apabila data tersebut diklasifikasikan dalam rentangan kadar kolesterol maka sebanyak 18 sampel atau 66,66\% tergolong memiliki kadar kolesterol yang baik ( $<200 \%$ $\mathrm{mg} / \mathrm{dl})$. Terdapat 7 orang atau $25 \%$ dari sample yang tergolong memiliki kadar kolesterol diambang batas tinggi $(200<x>240 \mathrm{mg} / \mathrm{dl})$ serta 2 orang atau 7,41\% memiliki kadar kolesterol yang tinggi ( $>240 \mathrm{mg} / \mathrm{dl})$.

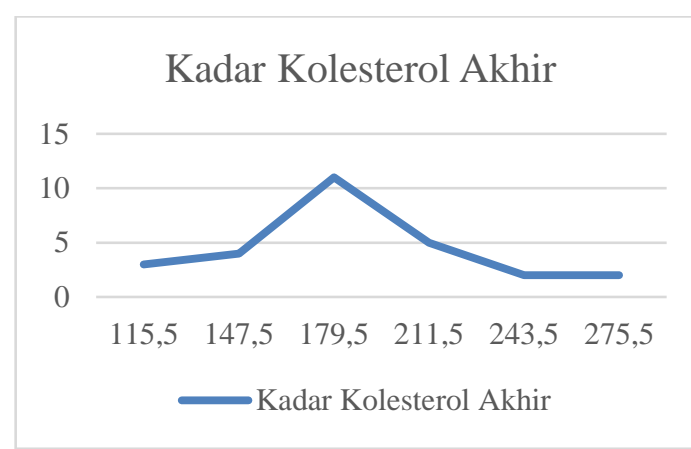

Gambar 24. Grafik Data Tes Akhir Kadar Kolesterol Total

Meskipun sebaran datanya hampir sama namun terlihat nilai tengah dari masing-masing kelas menunjukan penurunan yang berarti hampir seluruh sample mengalami penurunan kadar kolesterol total setelah aktifitas senam jantung sehat.

Tabel 4. Deskripsi Data Penelitian Tes Awal dan Tes Akhir Kadar Kolesterol Total

\begin{tabular}{|l|l|l|}
\hline Variabel & $\begin{array}{l}\text { Kadar Kolesterol } \\
\text { Total }\end{array}$ & $\begin{array}{l}\text { Kadar Kolesterol } \\
\text { Total }\end{array}$ \\
Awal(mg/dl) & Akhir(mg/dl) \\
\hline $\begin{array}{l}\text { Nilai } \\
\text { Tertinggi }\end{array}$ & 296 & 275 \\
\hline $\begin{array}{l}\text { Nilai } \\
\text { Terendah }\end{array}$ & 109 & 100 \\
\hline Rata - rata & 199,88 & 182,92 \\
\hline $\begin{array}{l}\text { Standar } \\
\text { deviasi }\end{array}$ & 40,31 & 40,08 \\
\hline $\begin{array}{l}\text { Standar } \\
\text { error }\end{array}$ & 7,92 & 7,87 \\
\hline \multicolumn{1}{|c|}{ Dari table deskripsi } & diatas terlihat
\end{tabular}
perbedaan yang cukup mencolok dimana nilai tertinggi untuk kadar kolesterol di awal ialah 296 mg/dl menurun sebesar $21 \mathrm{mg} / \mathrm{dl}$ menjadi 275 mg/dl di akhir aktifitas. Demikian juga pada nilai terendah yang semula $109 \mathrm{mg} / \mathrm{dl}$ menurun sebanyak $9 \mathrm{mg} / \mathrm{dl}$ menjadi hanya $100 \mathrm{mg} / \mathrm{dl} \mathrm{di}$ akhir treatment. Demikian juga terjadi pada rata-rata keseluruhan nilai kadar kolesterol total sampel yang semula $199.88 \mathrm{mg} / \mathrm{dl}$ menurun sejumlah $16,92 \mathrm{mg} / \mathrm{dl}$ menjadi hanya 182.92 $\mathrm{mg} / \mathrm{dl}$ di tes akhir penelitian. 


\section{Pengujian Hipotesis}

Hasil perhitungan kadar Kolesterol Total awal dan akhir diperoleh selisih rata-rata $\left(\mathrm{M}_{\mathrm{d}}\right)$ $16,92 \mathrm{mg} / \mathrm{dl}$ dengan Standar Deviasi Perbedaan $\left(\mathrm{SD}_{\mathrm{d}}\right) 6,84 \mathrm{mg} / \mathrm{dl}$. Standar Error perbedaan ratarata $\left(\mathrm{SE}_{\mathrm{md}}\right) 1,34 \mathrm{mg} / \mathrm{dl}$ dalam perhitungan selanjutnya diperoleh nilai t-hitung 12,63 dengan derajat kebebasan $(\mathrm{dk})=\mathrm{n}-1=27-1=26$ pada tarif signifikan $\alpha=0,05$ didapat sebesar 2,056 yang berarti t-hitung $=12,63$ lebih besar dari t-tabel $=2,056$. Hal ini menunjukan bahwa hipotesa nihil $\left(\mathrm{H}_{0}\right)$ ditolak dan Hipotesa Alternatif $\left(\mathrm{H}_{1}\right)$ diterima.

Dari hasil perhitungan tersebut menyatakan bahwa terdapat efek kerja senam jantung terhadap penurunan Kadar Kolesterol Total Pada Anggota Klub Jantung Sehat Mitra Pegangsaan, Jakarta Pusat.

\section{KESIMPULAN}

Berdasarkan masalah yang dikemukakan dan didukung dengan deskripsi teoretis, data penelitian yang ada, serta analisis data yang telah dilakukan maka dapat disimpulkanterdapat efek kerja senam jantung sehat terhadap penurunan kadar kolesterol total dengan rata-rata penurunan sebesar $16,92 \mathrm{mg} / \mathrm{dl}$ pada anggota Klub Jantung Sehat Mitra Pegangsaan, Jakarta Pusat.

Berdasarkan hasil penelitian yang diperoleh, maka peneliti ingin menyampaikan saran-saran sebagai berikut:

Kepada masyarakat terutama anggota Klub Jantung Sehat Mitra Pegangsaan untuk melakukan senam jantung sehat tertatur minimal 3 kali dalam 1 minggu.

Mensosialisasikan kepada seluruh masyarakat umum dalam melakukan olahraga yang baik ialah bersifat aerobik dengan intensitas ringan hingga sedang sebagai salah satu upaya pengontrol kadar kolesterol total.

Untuk pelatih dan instruktur maupun klub kesehatan lainnya agar memberikan pemahaman kepada para anggotanya akan manfaat dari melakukan senam jantung sehat.

Di dalam melakukan penelitian selanjutnya yang berhubungan dengan senam jantung agar jika mencari sampel harus diperhatikan untuk kemampuan masing-masing individu dalam melakukan treatment yang akan diberikan yaitu sampel yang mampu melakukan gerakan dengan baik dan benar secara maksimal.

\section{DAFTAR PUSTAKA}

Baraas, F. (1993). Mencegah Serangan Jantung dengan Menekan Kolesterol. Jakarta: Gramedia Pustaka Utama.

Brick, L. (2001). Bugar Dengan Senam Aerobik. Jakarta: PT. Raja Grafindo Persada.

Depdikbud. (1997). Petunjuk Pelaksanaan Pola Umum Pembinaan dan Pengembangan Kesegaran Jasmani. Jakarta: Pusat Kesegaran Jasmani dan Rekreasi Departemen Pendidikan dan Kebudayaan.

Dikpora. (2006). Petunjuk Olahraga Senam. Jakarta: Dinas Olahraga dan Pemuda Provinsi Daerah Khusus Ibu Kota Jakarta.

Dinata, M. (2010). Langsing Dengan Aerobik . Ciputat: Cerdas Jaya.

Fatmah. (2010). Gizi Usia Lanjut. Jakarta: Erlangga.

Garnadi, Y. (2011). Hidup Nyaman dengan Hiperkolesterol. Jakarta: Agromedia Pustaka.

Hairy, J. ( 2003). Daya Tahan Aerobik. Jakarta: Direktorat Jenderal Olahraga Departemen Pendidikan Indonesia.

Harsuki. (2003). Perkembangan Olahraga Terkini Kajian Para Pakar. Jakarta: PT Raja Grafindo Persada.

Yayasan Jantung Sehat Indonesia. (2001). Senam Jantung Sehat Seri IV. Jakarta: Badan Pelaksana Klub Yayasan Jantung Sehat Indonesia.

Yayasan Jantung Sehat Indonesia.. (2003). Senam Jantung Sehat seri I. Jakarta: 
Badan Pelaksana Klub Yayasan Jantung Sehat Indonesia.

Yayasan Jantung Sehat Indonesia. (2015). Senam Jantung Sehat Seri III. Jakarta: Badan Pelaksana Klub Yayasan Jantung Sehat Indonesia.

Kadir, A. (2007). Olahraga Pada Usia Lanjut (Lansia). Wijaya Kusuma, 1(1), 63-68.

Kamus, T. P. (1991). Kamus Besar Bahasa Indonesia Edisi Kedua . Jakarta: Departemen Pendidikan dan kebudayaan Balai Pustaka.

Lean, M. E. ( 2013). Ilmu Pangan, Gizi \& Kesehatan. Jakarta: Pustaka pelajar.

Pate, R. d. (1993). Dasar-dasar Ilmiah Kepelatihan. Semarang: IKIP Semarang Press.

Rodahi, P.-O. A. ( 1996). Textbook of Work Physiology. Sidney: International Student Edition. 